\title{
Sistem Pengendalian Persediaan Bahan Baku, Inventory dan Produksi pada Home Industry Mamake dengan Metode Reorder Point berbasis $W e b$
}

\author{
Wirantika Rahma Putri, Irma Permata Sari \\ Program Studi Teknik Informatika, \\ Jurusan Teknik Informatika dan Ko mputer \\ Politeknik Negeri Jakarta \\ wirantika.putri.tik14@ mhsw.pnj.ac.id ${ }^{1}, \underline{\text { Irma.permatasari@tik.pnj.ac.id }}{ }^{2}$
}

\begin{abstract}
Abstrak - Home Industry Mamake adalah industri rumahan di Kota Brebes yang memproduksi beberapa macam keripik, seperti keripik yang terbuat dari talas dan bawang merah. Dalam mengelola industri rumahan ini, HomeIndustry Mamake memiliki lima proses penting, yaitu pemesanan, pemasaran, produksi, inventory, dan pengendalian bahan baku. Terdapat masalah dalam proses produksi, inventory, dan pengendalian bahan baku yaitu semua proses masih dilakukan secara manual, dan bahkan tidak dilakukan pencatatan. HomeIndustry Mamake juga belum memiliki penentuan pengendalian persediaan bahan baku, sehingga sering mengal ami permasalahan terhadap jumlah persediaan bahan baku. Tujuan dari penelitian ini yaitu membuat sistem pengendaian bahan baku, inventory, dan produksi dengan menggunakan metode pengendalian persediaan bahan baku. Sebuah metode pengendalian bahan baku bernama reorderpoint (ROP) mengendalikan bahan baku dengan cara menentukan batas stok minimal bahan baku yang harus dimiliki perusahaan, dan ketika ada di titik stok tersebut, perusahaan harus melakukan pemesanan bahan baku kembali agar tidak terjadi kekurangan dan penumpukan persediaan bahan baku. Berdasarkan hasil analisis, perancangan, dan implementasi yang sudah dilakukan, maka dapat diambil kesimpulan bahwa modul pengendalian bahan baku, produksi, dan inventory berhasil dibuat menggunakan metode ROP atau titik pemesanan kembali.
\end{abstract}

Kata Kunci : Codeigniter, Rational Unified Process (RUP), Reorder Point (ROP).

\section{PENDAHULUAN}

Dalam mengelola industri rumahan ini, Home Industry Mamake memiliki lima proses penting, yaitu pemesanan, pemasaran, produksi, inventory, dan pengendalian bahan baku.Berdasarkan hasil wawancara, terdapat masalah dalam proses produksi, inventory, dan pengendalian bahan baku yaitu semua proses masih dilakukan secara manual. Pada proses produksi pengelolaan data masih dilakukan secara manual, dan bahkan tidak dilakukan pencatatan setiap melakukan produksi. Proses inventory untuk mengetahui jumlah stok bahan baku, produk yang dihasilkan, dan alat-alat yang digunakan juga masih dilakukan secara manual. Home Industry Mamake juga belum memiliki penentuan pengendalian persediaan bahan baku, sehingga sering mengalami permasalahan terhadap jumlah persediaan bahan baku. Penumpukan persedian ataupun kekurangan persediaan bahan baku akan mengakibatkan pengeluaran biaya yang semakin tinggi dan penggunaan waktu yang lebih lama.

Sebuah jurnal tentang pengendalian persediaan bahan baku yang berjudul "Desain Aplikasi Pengendalian Persediaan Bahan Baku dengan Metode Titik Pemesanan Kembali (Studi Kasus Rumah Makan Ayam Cobloos Bekasi)"[1]mengatakan bahwa metode reorder point (ROP) dapat digunakan untuk mengendalikan persediaan bahan baku. Namun pada penelitian ini, penentuan titik ROP tidak terakumulasi secara otomatis. User harus menghitung manual terlebih dahulu parameter-parameter yang diperlukan untuk menentukan titik ROP.

Berdasarkan masalah yang melatarbelakangi perusahaan tersebut maka dibangunlah sistem pengendalian persediaan bahan baku, inventory, dan produksi pada home industry mamake dengan metode reorder point berbasis web. Sistem informasi ini akan membantu Home Industry Mamake dalam menentukan titik ROP bahan baku secara otomatis dan user tidak perlu lagi menghitungmanual parameter-parameter yang diperlukan untuk menentukan titik ROP bahan baku. Selain itu sistem ini adalah sarana pembukuan terkomputerisasi untuk pengelolaan data pengendalian bahan baku, inventory, dan produksi pada HomeIndustry Mamake. 
Penelitian ini merupakan hasil orisinil, karena sebelumnya belum ada penelitian yang membuat sistem informasi pengendalian bahan baku yang dapat menentukan titik ROP secara otomatis tanpa menghitung manual parameter-parameter yang dibutuhkan untuk mendapatkan titik ROP.

\section{LANDASAN TEORI}

\section{A. Pengendalian Persediann Bahan Baku.}

Pengendaliaan persediaan adalah suatu teknik yang menetapkan besarnya persediaan bahan yang harus diadakan untuk menjamin kelancaran dalam kegiatan operasional produksi, serta menetapkan jadwal pengadaan dan jumlah pemesanan barang yang seharusnya dilakukan oleh perusahaan[2]. Sedangkan bahan baku adalah bahan yang digunakan untuk membuat produk selesai. Bahan baku dapat diidentifikasikan ke produk dan merupakan bagian integral dari produk tersebut [3]. Dalam sebuah perusahaan bahan baku memiliki arti yang sangat penting, karena menjadi modal terjadinya proses produksi sampai hasil produksi. Pengendalian bahan diprioritaskan pada bahan yang nilainya relative tinggi yaitu bahan baku. Dapat disimpulkan bahwa pengendalian persediaan bahan baku adalah suatu teknik penetapan besarnya persediaan bahan baku yang harus diadakan untuk menjamin kelancaran dalam kegiatan operasional produksi. Karena bahan baku menjadi modal terjadinya proses produksi sampai hasil produksi.

\section{B. Inventory}

Inventory adalah proses penyediaan bahan baku dalam suatu perusahaan untuk di produksi, serta barang jadi yang di sediakan untuk memenuhi permintaan dari konsumen setiap waktu siap pakai.Secara umum pengertian inventory adalah suatu aset yang ada dalam bentuk barang-barang yang dimiliki perusahaan[4]. Inventory meliputi semua barang yang dimiliki perusahaan, semua barang yang berwujud dapat disebut sebagai inventory, tergantung dari sifat dan jenis usaha perusahaan. Inventory berfungsi untuk melindungi kelangsungan produksi dan pemenuhan permintaan pelanggan.

\section{Produksi}

Produksi adalah usaha manusia untuk mengubah serta mengolah sumber daya ekonomi menjadi bentuk serta kegunaan baru. Dengan kata lain, kegiatan produksi adalah proses mengolah produk yang dapat berupa barang dan jasa[5]. Proses produksi menggunakan faktor-faktor yang ada seperti tenaga kerja, mesin, bahan baku, dan dana untuk menciptakan atau menambah kegunaan suatu barang dan jasa agar lebih bermanfaat bagi kebutuhan manusia.

\section{Website dinamis}

Website dinamis adalah website yang isinya dirancang untuk sering berubah dan ditulis dalam bahasa pemrograman dan database[6]. Dalam pembuatan website dinamis sudah dirancang semudah mungkin bagi user yang akan menggunakan website dinamis tersebut. Untuk pengubahan content atau isi dokumen dalam sebuah website dinamis, tidak perlu memiliki keahlian programming atau seorang programmer saja yang dapat mengubah isi dokumen pada website dinamis.

\section{E. Framework Codeigniter}

Framework Codeigniter adalah sebuah framework bahasa pemrograman PHP yang bersifat open source, object oriented programming (OOP), dan berkonsep model, view, controller (MVC). Dengan MVC, maka memungkinkan pemisahan antara layer application logic dan presentation sehingga dalam sebuah pengembangan web, seorang programmer bisa berkonsentrasi pada core system, sedangkan webdesigner bis a berkonsentrasi pada tampilan web. Codeigniter ditulis dengan menggunakan bahasa php versi 4 dan versi 5 oleh Rick Ellislab yang menjadi CEO Ellislab, Inc. dan dipublikasikan dengan lisensi di bawah Apache/BSD Open Source[7].

\section{METODOLOGI}

Metode titik pemesanan kembali (Reorder Point) adalah suatu metode untuk mengendalikan persediaan bahan baku. ROP berguna untuk mengetahui kapan suatu perusahaan mengadakan pemesanan. Terjadi apabila jumlah persediaan yang terdapat dalam stock berkurang terus sehingga harus ditentukan berapa banyak batas minimal tingkat persediaan yang harus dipertimbangkan sehingga tidak terjadi kekurangan persediaan.

ROP adalah suatu titik ketika perusahaan harus mengadakan pemesanan kembali sedemikian rupa sehingga kedatangan atau penerimaan material yang dipesan itu tepat pada saat persediaan di titik nol atau pada tingkat safety stock[8]. Dalam menentukan menetapkan ROP harus memperhatikan hal-hal berikut:

$$
\mathrm{ROP}=(\mathrm{LT} \times \mathrm{D})+\text { safety stock }
$$

Keterangan:

1. Safety Stock $(\mathrm{SS})=$ Standar Deviasi(SD) $\mathrm{x}$ ServiceFactor $(\mathrm{Z})$

2. Penggunaan Perhari $(D)=$ Jumlah Persediaan / $\mathrm{t}$ (waktu kerja dalamsatuan hari) 
3. Leadtime $(\mathrm{LT})=$ waktu yang dibutuhkan antara pemesanandengan barang sampai di perusahaan

\section{HAS IL DAN PEMBAHASAN}

A. Implementasi pada Basis Data

Tabel-tabel yang terdapat pada basis data dapat digambarkan seperti gambar dibawah ini :

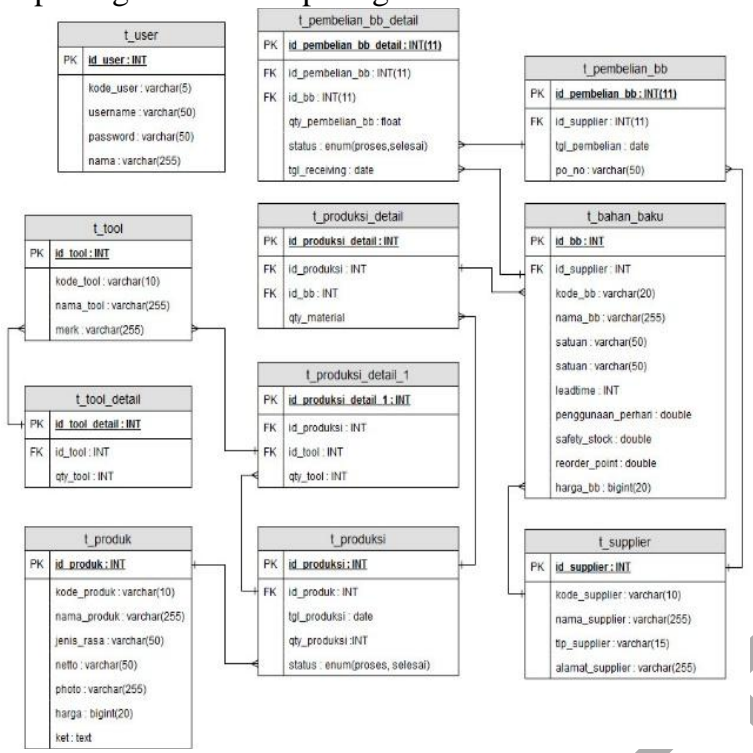

Gambar 1 Relasi Database

\section{B. Implementasi Pemrograman} titik ROP

Berikut adalah script SQL untuk perhitungan

create view v_rop as

t_bahan_baku.id_bb,

t_pembelian_bb_detail.tgl_receiving,

t_bahan_baku.nama_bb

SUM(t_pembelian_bb_detail.qty_pembelian_bb) as subjuml ah,

STD(t_pembelian_bb_detail.qty_pembelian_bb) as SD ,

(STD (t_pembelian_bb_detail.qty_pembelian_bb) * 1.281551566) as SS,

tdate.daterange as waktukerja,

(SUM ( t_pembelian_bb_detail.qty_pembelian_bb)/td ate.daterange) as penggunaanperhari,

t_bahan_baku.leadtime,

( (t_bahan_baku. leadtime*

SUM(t_pembelian_bb_detail.qty_pembelian_bb)/tda

te.daterange) +

STD(t_pembelian_bb_detail.qty_pembelian_bb) *

1.281551566) as ROP

FROM ‘t_pembelian_bb_detail'inner join

t_bahan_baku on t_pembelian_bb_detail.id_bb =

t_bahan_baku.id_bb cross join (select

DATEDIFF(MAX (tgl_receiving),
MIN(tgl_receiving)) as daterange from

t_pembelian_bb_detail) tdate GROUP BY

t_bahan_baku.id_bb

Dalam kode SQL tersebut, terdapat beberapa langkah untuk mendapatkan nilai ROP. Berikut adalah tiga tahap untuk mendapatkan nilai ROP:

1) Safety Stock (SS) = Standar Deviasi (SD) $\mathrm{x}$ Service Factor (Z).

Service factor berasal dari servicelevel. Ditetapkan servicelevel dari HomeIndustry Mamake adalah 90\%, oleh karena itu servicefactor dari servicelevel $90 \%$ adalah 1,281551566 .

2) Penggunaan Perhari (D) = Jumlah Persediaan / t (waktu kerja dalam satuan hari).

3) Reorder point $(\mathrm{ROP})=(\mathrm{LT} \times \mathrm{D})+\mathrm{SS}$

\section{Implementasi Antar Muka}

\section{Dashboard}

Dashboard merupakan halaman utama yang berisi informasi statistik bahan baku masuk dan keluar, lalu juga terdapat alert bahan baku yang sudah berada di titik ROP dan yang kurang dari titik ROP.

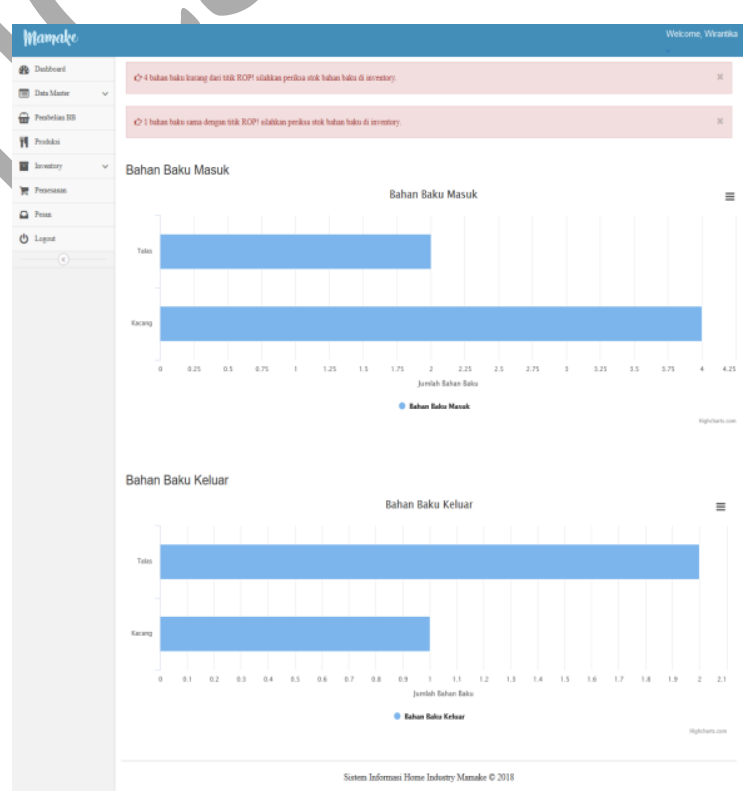

Gambar 2 Halaman Dashboard

\section{Halaman Tampil Data Pembelian Bahan Baku}

Halaman tampil data pembelian bahan baku merupakan halaman yang menampilkan tampil data pembelian bahan baku dalam bentuk tabel. Berikut adalah screenshoot dari halaman tampil data pembelian bahan baku. 


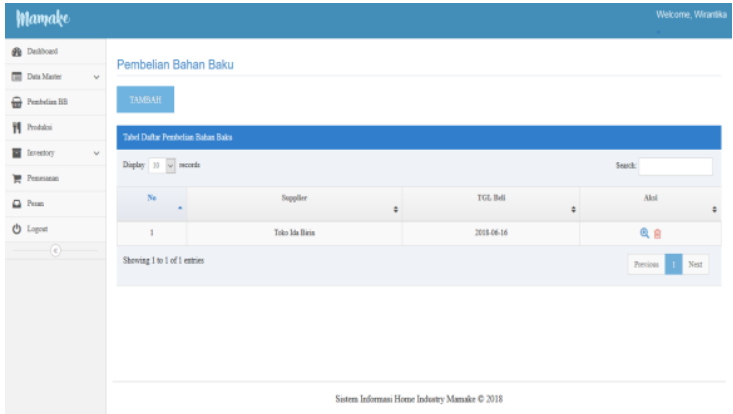

Gambar 3 Halaman Tampil Data Pembelian Bahan Baku

3. Halaman Tambah Data Pembelian Bahan Baku

Halaman tambah data pembelian bahan baku merupakan halaman untuk menambahkan data bahan baku. Berikut merupakan screenshoot dari halaman tambah data pembelian bahan baku.

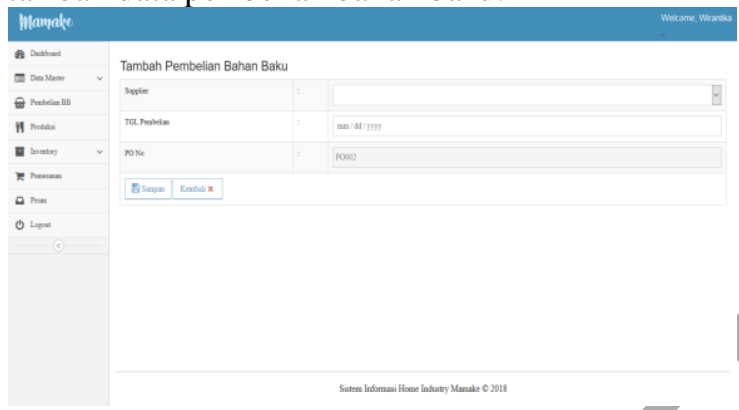

Gambar 4 Halaman Tambah Data Pe mbelian Bahan Baku

\section{Halaman Tambah Data Detail Pembelian Bahan} Baku

Halaman tambah data detail pembelian bahan baku merupakan halaman untuk menambahkan data detail bahan baku yang akan dibeli. Berikut merupakan screenshoot dari halaman tambah data pembelian bahan baku.

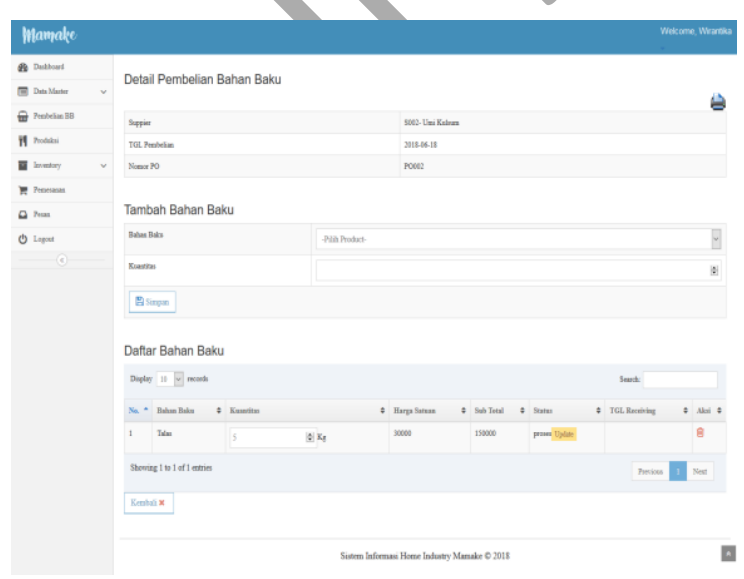

Gambar 5 Halaman Tambah Data Detail Pembelian BB

\section{Halaman Tampil Data Produksi}

Halaman tampil data produksi merupakan halaman yang menampilkan tampil data produksi dalam bentuk tabel. Berikut adalah screenshoot dari halaman tampil data produksi.

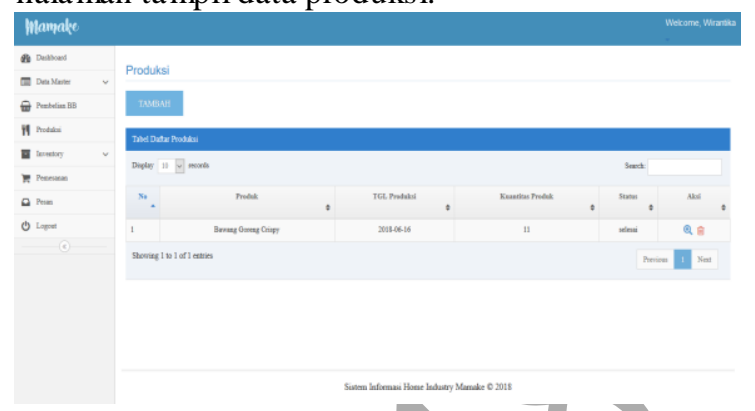

Gambar 6 Halaman Tambah Data Produksi

6. Halaman Tambah Data Produksi

Halaman tambah data detail produksi merupakan halaman untuk menambahkan data detail bahan baku yang akan digunakan untuk memproduksi produk. Berikut merupakan screenshoot dari halaman tambah data produksi.

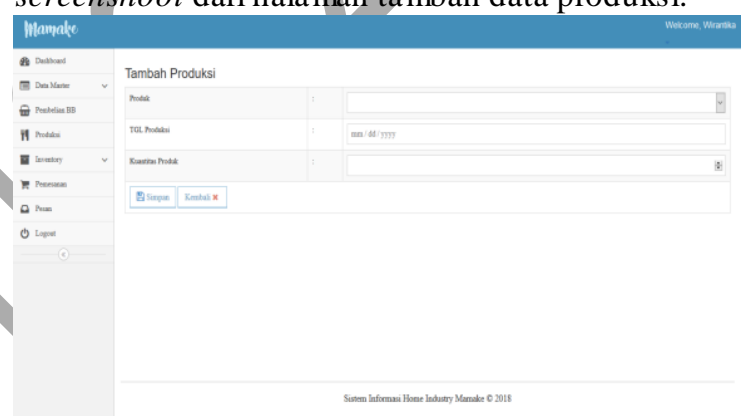

Gambar 7 Halaman Tambah Data Produksi

\section{Halaman Tampil Data Stok Bahan Baku}

Halaman tampil data stok bahan baku adalah halaman yang menampilkan tabel yang berisi data stok bahan baku. Berikut merupakan screenshoot dari hala man tampil data stok bahan baku.

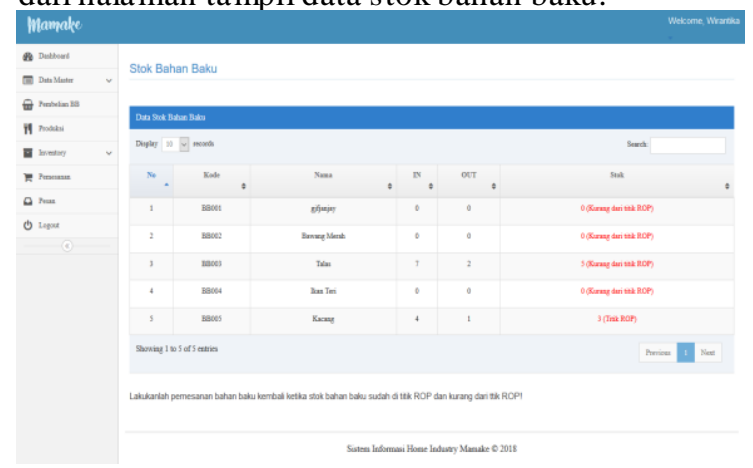

Gambar 8 Halaman Tampil Data Stok BB

\section{Analisis Data}

Berikut merupakan perbandingan hasil perhitungan titik reorder point menggunakan perangkat lunak lembar sebar microsoft excel dan 
implementasi pada modul pengendalian bahan baku sistem informasi Home Industry Mamake. TABEL 1 merupakan tabel perhitungan titik ROP menggunakan perangkat lunak lembar sebar micros oft excel.

\section{TAB EL 1 Hasil Perhitungan ROP Menggunakan} MS Excel

\begin{tabular}{|c|c|c|c|}
\hline \multirow[b]{2}{*}{ No } & \multirow[b]{2}{*}{$\begin{array}{c}\text { Periode } \\
\text { Pemesanan }\end{array}$} & \multicolumn{2}{|c|}{$\begin{array}{c}\text { Jumlah Kebutuhan Bahan } \\
\text { Baku }\end{array}$} \\
\hline & & $\begin{array}{l}\text { Talas } \\
(\mathrm{kg})\end{array}$ & Kacang (Kg) \\
\hline 1 & 1 & 75 & 4,2 \\
\hline 2 & 2 & 78 & 4,5 \\
\hline 3 & 3 & 81 & 4,7 \\
\hline 4 & 4 & 69 & 4 \\
\hline 5 & 5 & 78 & 4,5 \\
\hline 6 & 6 & 75 & 4,2 \\
\hline 7 & 7 & 73,5 & 4 \\
\hline 8 & 8 & 69 & 4 \\
\hline 9 & 9 & 81 & 4,5 \\
\hline 10 & 10 & 78 & 4,5 \\
\hline 11 & 11 & 75 & 4,5 \\
\hline 12 & 12 & 77 & 4,7 \\
\hline \multicolumn{2}{|c|}{ Jumlah } & 909,5 & 52,3 \\
\hline \multicolumn{2}{|c|}{$\begin{array}{l}\text { Standar Deviasi } \\
\text { (SD) }\end{array}$} & 3,76086 & 0,25317429 \\
\hline \multicolumn{2}{|c|}{ Service Level } & \multicolumn{2}{|r|}{$90 \%$} \\
\hline \multicolumn{2}{|c|}{ Service Factor $(\mathrm{Z})$} & \multicolumn{2}{|c|}{1,281551566} \\
\hline \multicolumn{2}{|c|}{ Safety Stock (SS) } & 4,81974 & 0,32445591 \\
\hline \multicolumn{2}{|c|}{ Waktu Kerja (t) } & \multicolumn{2}{|r|}{90} \\
\hline \multicolumn{2}{|c|}{$\begin{array}{c}\text { Penggunaan } \\
\text { Perhari (D) }\end{array}$} & 10,1056 & 0,58111111 \\
\hline \multicolumn{2}{|c|}{ Leadtime (LT) } & 3 & 3 \\
\hline \multicolumn{2}{|c|}{ ROP } & 35,1364 & 2,06778924 \\
\hline
\end{tabular}

Keterangan:

a. Safety Stock $(\mathrm{SS})=$ Standar Deviasi $(\mathrm{SD}) \mathrm{x}$ Service Factor (Z)

b. Penggunaan Perhari (D) = Jumlah Persediaan $/ \mathrm{t}$ (waktu kerja dalam satuan hari)

c. Reorder point $(\mathrm{ROP})=(\mathrm{LT} \times \mathrm{D})+\mathrm{SS}$

Gambar 9 merupakan tabel data pembelian bahan baku pada database sistem informasi Home Industry Mamake yang dikelola melalui modul pengendalian bahan baku sistem informasi Home Industry Mamake.

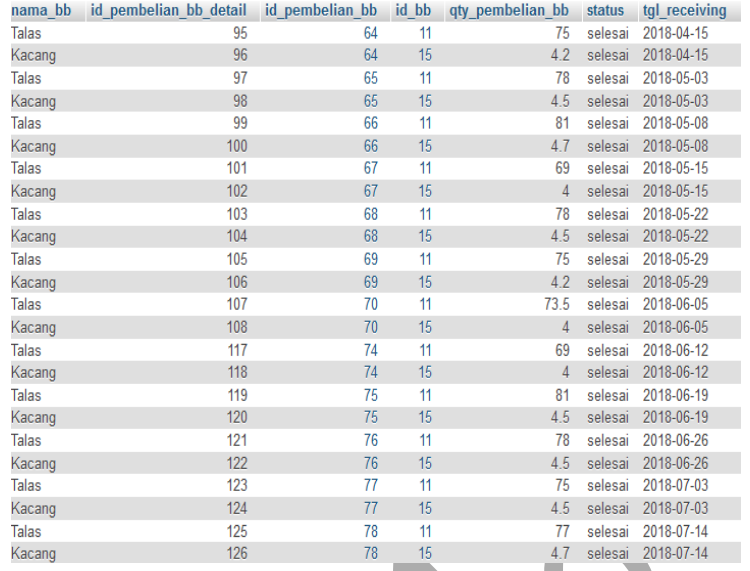

Gambar 9 Tabel Pe mbelian BB

Dari data pada Gambar 4.9 dapat dihasilkan safety stock (SS) dan penggunaan perhari (D) untuk menghitung titik reorder point (ROP). Gambar 4.10 merupakan hasil perhitungan titik ROP dari hasil olah data pembelian bahan baku yang ada pada Gambar 9.

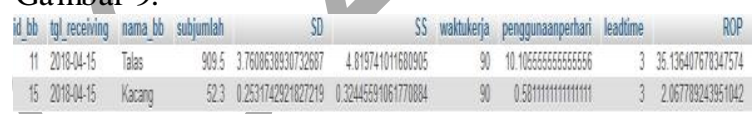

Gambar 10 Hasil Perhitungan ROP Modul Pengendalian BB

Berdasarkan hasil pengujian dengan perbandingan data pada TABEL 1 dengan Gambar 10 dapat disimpulkan bahwa perhitungan titik ROP yang dihasilkan menggunakan perangkat lunak lembar sebar microsoft excel dan modul pengendalian bahan baku sistem informasi Home Industry Mamake adalah sama.

\section{KES IMPULAN}

Berdasarkan hasil perancangan, implementasi, dan analisis yang sudah dilakukan, dapat disimpulan bahwa modul pengendalian bahan baku, produksi, dan inventory telah dibuat menggunakan metode pengendalian bahan baku reorderpoint (ROP) atau titik pemesanan kembali. Dari analisis data perhitungan menggunakan SQL program ROP pada sistem dan hitung ROP manual dengan exel diketahui bahwa hasil perhitungan $100 \%$ adalah sama. Sistem ROP ini bergunauntuk mengetahui kapan suatu perusahaan mengadakan pemesanan. Selain itu sistem ini adalah sarana pembukuan terkomputerisasi untuk pengelolaan datapengendalian bahan baku, inventory, dan produksipada HomeIndustry Mamake.

Adapun saranterkait pengembangan sistem adalah penambahan fitur cetak laporan transaksi pembelian bahan baku dan penjualan produk, serta menambahkan metode peramalan penjualan produk. 


\section{REFERENS I}

[1] C. S. Putri, Kastaman, and E. Suprihatin, "Desain Aplikasi Pengendalian Persediaan Bahan Baku Dengan Metode Titik Pemesanan Kembali ( Studi Kasus Rumah Makan Ayam Cobloos Bekasi )," Semin. Nas. Teknol. Inf. Multimed., p. 3.3-103-3.3-108, 2016.

[2] M. Sahli and S. Nanik, "Penerapan Metode Exponentia Smoothing Dalam Sistem Informasi Pengendalian Persediaan Bahan Baku (Studi Kasus Toko Tirta Harum)," J. SIMETRIS, vol. 3, no. 1, pp. 59-69, 2013. H. P. Gerungan, "Pendekatan target costing sebagai alat penilaian efisiensi produksi pada PT.Tropica Cocoprima," Emba, vol. 1, no. 3, pp. 863-870, 2013.

[4] M. Rohayati, "Membangun Sistem Informasi Monitoring Data Inventory Di Vio Hotel Indonesia," J. Ilm. Komput. dan Inform., vol. 1, no. 1, pp. 1-8, 2014.

[5] A. Kusnadi and J. Pratama, "Implementasi Algoritma
Genetika dan Neural Network Pada Aplikasi Peramalan Produksi Mie (Studi Kasus: Omega Mie Jaya)," vol. IX, no. 1, pp. 37-41, 2017.

[6] D. S. Djaeng and B. Burhanudin, "Analisa Kualitas Website STMIK Bina Mulia Palu Menggunakan Framework WebQual," J. Elektron. Sist. Inf. dan Komput., vol. 2, no. 2, pp. 53-63, 2016.

[7] P. Oktivasari and Z. F. Suhardi, "PENGEMBANGAN FITUR DOWNTIME REPORTING DAN MODUL SUMMARY PADA SISTEM MONITOR DAN PELAPORAN OPERASIONAL MESIN eCRM," vol. 9, no. 1, pp. 46-53, 2016.

[8] R. I. Asari, H. B. Setyawan, and V. Nurcahyawati, "Rancang Bangun Sistem Informasi Pengendalian Persediaan Bahan Baku dengan Menggunakan Metode Reorder Point," JSIKA, vol. 6, no. 2, 2011. 